\title{
LEADERSHIP EFFECTIVENESS IN RELATION WITH JOB SATISFACTION
}

\author{
Hakeem Sayar Ahmad Shah, Mahmood Ahmad Khan
}

Research Scholar, Department Of Education, University Of Kashmir, Srinagar, India

sayaredu@Gmail.Com

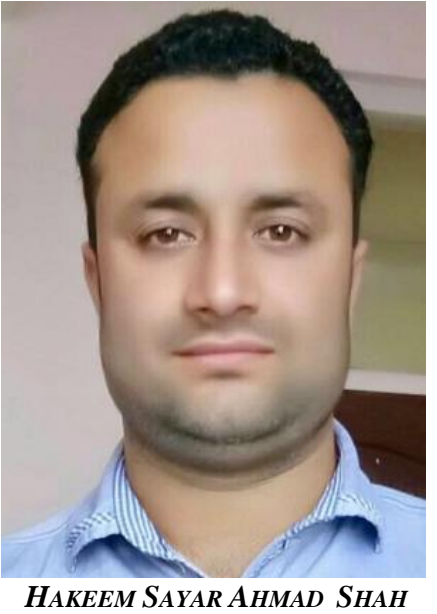

Keywords:

Leadership Effectiveness,

Job Satisfaction

and Headmasters

\begin{abstract}
A B S T R A C T
The present study was conducted to find out the relationship between Leadership Effectiveness and Job Satisfaction of Secondary School Headmasters. 300 Secondary School Headmasters served as a sample for this study, which were selected from Kashmir Valley by using a random sampling technique. The required data was collected with the help of Leadership Effectiveness Scale developed by Taj (2010) and Job Satisfaction Scale developed by Singh and Sharma (2006). The results of the study revealed a positive and significant relationship between Interpersonal relations dimension of Leadership Effectiveness \& Composite score of Job Satisfaction; Intellectual Operations dimension of Leadership Effectiveness \& Job Concrete factor of Job Satisfaction; Behavioural \& Emotional Stability dimension of Leadership Effectiveness \& Psycho-Social factor of Job Satisfaction; Operation as a Citizen dimension of Leadership Effectiveness \& Community/National Growth factor of Job Satisfaction.
\end{abstract}

Citation: Hakeem Sayar Ahmad Shah, Mahmood Ahmad Khan. (2018). Face Recognition In Java Environment. International Journal of Advanced Multidisciplinary Scientific Research Java Environment. International Journal of Advanced Multidisciplina
(IJAMSR ) ISSN:2581-4281 Vol 1, Issue 5, July, 2018, \#Art.520, pp 50-57

\section{Introduction}

The headmaster is the key educational leader and the chief executive officer of a complex and diverse community comprising of renowned, committed and dedicated teaching staff, students, their parents, governing bodies, education departments. Leaders do not belittle people or make them feel that they have nothing to contribute. Leaders don't hide in their offices to 


\section{International Journal of Advanced Multidisciplinary Scientific Research (IJAMSR) ISSN:2581-4281}

overlook problems. They have to be visible; they have to convey a sense of oneness (Gupta, 1987).

Leadership is defined as a process by which an individual attempts to influence other group members towards achieving group goals. Leadership is also viewed as a process which people use to bring out the best in themselves and others. National culture is said to play a pivotal role in determining the effectiveness of leadership styles. Leadership Effectiveness is usually accepted as a key component to achieve school progress. Kauts \& Sharma, (2017) found that schools with high effectiveness have more effective leadership as compared to low leadership effective schools. It was also found that female principals are more effective as compared to male principals. Voilet, (2016) found that autocratic and democratic leadership styles were highly effective. As well, the administrative competence and school administrator's skills of principals were effective. Democratic leadership style has been found to have a positive impact on teacher's job satisfaction (Nadarasa \& Thuraisingam, 2014). Effectiveness of deans is largely influenced by inadequate leadership competences and grooming, the absence of clearly defined and well communicated job descriptions as well as performance management practices that seek accountability of deans (Alabi \& Alabi, 2014). Leadership behavior and communication methods were found to have significantly associated to administrative effectiveness of heads of educational departments (Adamu \& Ajayi, 2010). Positive and significant relation has been found between teacher's perception about organizational commitment and supportive leadership behavior of school administrators (Cokluk \& Yilmaz, 2010). Influence, power and authority which enable the leader to effectively transform the organization through the direction of the human resources are essential organizational assets, for achieving the desired results (Armstrong, 2004).

Job satisfaction is regarded as a generally favorable or unfavorable attitude resulting from specific work areas, such as job factors and individual characteristics (Blum and Naylor, 1968). Mocheche, et al., (2017) found that female teachers are slightly high score as compared to male teachers in the level of job satisfaction. Job satisfaction is viewed as a crucial factor in the general efficiency of an organization. Mumtaz, et al., (2016) found that the majority of the high secondary school heads were satisfied with their job intrinsically and extrinsically except five dimensions, i.e. ability utilization, supervision (HR), supervision (technical), school policies and working conditions. (Raza, et al., 2015) found a positive and significant association between four intrinsic facets of job satisfaction: creativity, job security, responsibility and achievement with job satisfaction. A positive relationship has been found between reward and recognition, satisfaction with supervision and job characteristics (Nguyen, et al., 2013). Head teachers of elementary schools were slightly satisfied with respect to their promotion, formulation, awareness and implementation of education policy and salary packages. They also found that head teachers were satisfied with respect to factors of a job, i.e. ability utilization, achievement from a job, administrative activities, authority, creativity, independence in administration and teaching, moral values and other factors (Ali, et al., 2012). Job satisfaction has a core relationship with several attitudes about the job characteristic, compensation and benefits, social status, social security, promotion, technological challenges and respect (Tella, et al., 2007). 
The present study is concerned leadership effectiveness in relation with job satisfaction of secondary school headmasters. Studies have been conducted on leadership effectiveness \& job satisfaction, but these studies have been conducted on bank officials, commercial and business organizational managers, university officials, college principals, rural \& urban teachers, government and private primary school heads in foreign conditions. But very few studies have been conducted on leadership effectiveness in relation to job satisfaction in India and no such study has been conducted on the selected variables particularly in Jammu and Kashmir State. Hence, the investigators thought that there is a need to study leadership effectiveness in relation to job satisfaction.

\section{Objective}

- To find the relationship between Leadership Effectiveness on various (Dimensions \& Composite Score) and Job Satisfaction on various (Factors \& Composite Score) of Secondary School Headmasters.

\section{Hypothesis}

- There is a significant relationship between Leadership Effectiveness of various (Dimensions \& Composite Score) and Job Satisfaction on various (Factors \& Composite Score) of Secondary School Headmasters.

\section{Operational Definition Of Variables}

- Leadership Effectiveness: Effective leaders inspire followers to achieve personal or collective mastery of the capacities needed to accomplish "collective aspirations (Leithwood, et al., 1999).

Leadership effectiveness in this present investigation refers to the dominant set of scores obtained by the sample subjects on the Leadership Effectiveness Scale developed by Taj (2010).

- Job Satisfaction: Job satisfaction as a combination of psychological, physiological, and environmental circumstances that cause a person to be truly satisfied with his or her job (Frank, 1986). Job satisfaction in the present investigation refers to the dominant set of scores obtained by the sample subjects on the Job Satisfaction Scale developed by Singh and Sharma (2006).

\section{Design Of The Study}

\section{Sample}

The sample for the present study consisted of 300 secondary school headmasters working in various high schools of Kashmir Valley. They were drawn by adopting random sampling technique. The procedure for drawing the sample was adopted by procuring the list of all the high schools of Kashmir Valley from the Directorate of School Education Kashmir Province. It included 820 high schools run by the Government of Jammu and Kashmir. Thereafter, 300 Secondary School Headmasters were selected randomly. 
https://doi.org/10.31426/ijamsr.2018.1.5.520

I J A M S R

International Journal of Advanced Multidisciplinary Scientific Research (IJAMSR) ISSN:2581-4281

\section{Selection And Description Of Tools}

The investigator, after screening a number of available tests, finally selected the following standardized tools for the collection of data:

- $\quad$ Leadership Effectiveness Scale (LES): This scale is developed by Taj (2010) was used to measure the Leadership Effectiveness. It has 79 questions.

- Job Satisfaction Scale (JSS): This scale is developed by Singh and Sharma (2006). It measures the Job Satisfaction of everybody, contains 30 items, it is standardized on Principals, teachers, engineers, advocates and doctors.

\section{Statistical Treatment Of Data}

The collected information was subjected to statistical treatment by calculating Coefficient of Correlation. The purpose was to find if there exists any relationship between Leadership Effectiveness \& Job Satisfaction of Secondary School Headmasters.

\section{Analysis}

Table: 1 Showing Coefficient of Correlation between Leadership Effectiveness and Job Satisfaction of Secondary School Headmasters on various (Dimensions \& Composite Score)

\begin{tabular}{|c|c|c|c|c|c|c|}
\hline & \multicolumn{6}{|c|}{ Job Satisfaction } \\
\hline $\begin{array}{l}\text { Leadership } \\
\text { Effectivenes } \\
\text { s }\end{array}$ & JCF & $\begin{array}{c}\text { JA } \\
\mathbf{F}\end{array}$ & PSF & $\mathbf{E F}$ & $\underset{\mathrm{F}}{\mathrm{CNG}}$ & $\begin{array}{c}\text { Composit } \\
\text { e Score }\end{array}$ \\
\hline IPR & .020 & .094 & .077 & $\begin{array}{c}.09 \\
6\end{array}$ & .027 & $.148^{*}$ \\
\hline IO & .131 & .020 & .016 & $\begin{array}{c}- \\
.01 \\
3\end{array}$ & -.009 & -.065 \\
\hline BES & .040 & .053 & $\begin{array}{l}.121 \\
*\end{array}$ & $\begin{array}{c}.01 \\
1\end{array}$ & .059 & .069 \\
\hline EMS & .071 & .002 & .014 & $\begin{array}{c}.06 \\
2\end{array}$ & -.026 & .051 \\
\hline AOC & .083 & .045 & .059 & $\begin{array}{c}.01 \\
3\end{array}$ & .069 & .008 \\
\hline OAC & .051 & $\begin{array}{c}- \\
.080\end{array}$ & -.071 & $\begin{array}{c}- \\
.07 \\
0\end{array}$ & $.130^{*}$ & -.050 \\
\hline $\begin{array}{l}\text { Composite } \\
\text { Score }\end{array}$ & $\begin{array}{c}- \\
.019\end{array}$ & $\begin{array}{c}- \\
.006\end{array}$ & .029 & $\begin{array}{c}.05 \\
6\end{array}$ & .042 & .051 \\
\hline
\end{tabular}

Acronyms:

\begin{tabular}{|l|l|l|}
\hline JCF & $:$ & Job Concrete Factor \\
\hline JAF & $:$ & Job-Abstract Factor \\
\hline PSF & $:$ & Psycho-Social Factor \\
\hline EF & $:$ & Economic Factor \\
\hline CNGF & $:$ & Community/National Growth Factor \\
\hline IR & $:$ & Interpersonal Relations \\
\hline IO & $:$ & Intellectual Operations \\
\hline BES & $:$ & Behavioral \& Emotional Stability \\
\hline EMS & $:$ & Ethical \& Moral Strength \\
\hline AOC & $:$ & Adequacy of Communication \\
\hline OAC & $:$ & Operations as a Citizen \\
\hline
\end{tabular}




\section{International Journal of Advanced Multidisciplinary Scientific Research (IJAMSR) ISSN:2581-4281}

\section{Interpretation And Discussion}

The results given in the table no. 1 shows the coefficient of correlation between Interpersonal Relation dimensions of Leadership Effectiveness and various factors of Job Satisfaction like (Job Concrete factor.020, Job Abstract factor.094, Psycho-Social factor. 077, Economic factor.096, and Community /National Growth factor. 027). The coefficient of correlation between interpersonal relations dimension of Leadership Effectiveness and various factors of Job Satisfaction is not significant. The association between Interpersonal relations dimension of Leadership Effectiveness and composite scores of Job Satisfaction is.148 which is positive and significant at 0.05 level of significance. This clearly indicates that Interpersonal relations dimension of Leadership Effectiveness is significantly related with Composite score of Job Satisfaction of Secondary School Headmasters only.

A perusal of table no. 1 also shows the coefficient of correlation between the Intellectual Operations dimension of Leadership Effectiveness and various factors of Job Satisfaction. The association between intellectual operations and Job Concrete factor is .131 which is positive and significant at 0.05 level. The results make it clear that intellectual operation dimension and job concrete factor of Job Satisfaction go together. The correlation between Intellectual Operations dimension and various factors of Job Satisfaction is (Job Abstract factor is -.020), (Psycho-Social factor is .016), (Economic factor is -.013), (Community/National Growth factor is -.009) is not significant. The correlation between the Intellectual Operation dimension of Leadership Effectiveness and composite scores of Job Satisfaction is (-. 065) is negative but not significant.
The results presented in the table no. 1 shows the coefficient of correlation between Behavioral and Emotional Stability dimension of Leadership Effectiveness and various factors of Job Satisfaction like (Job Concrete factor.040), (Job Abstract factor.053), (Psycho-Social factor.121), (Economic factor.011), (Community/National Growth factor.059) and with a composite score of Job Satisfaction is (. 069). The results indicate that there is a positive and significant correlation at 0.05levels between Behavioral and Emotional Stability dimension of Leadership Effectiveness and Psycho-Social factor of Job Satisfaction. The results reveal that Secondary School Headmasters who have high Behavioral and Emotional Stability are also having high Psycho-Social attitude. It was also found that the correlation between Behavioral and Emotional Stability dimension of Leadership Effectiveness and composite scores of Job Satisfaction is not significant.

The perusal of table no. 1 reveals the coefficient of correlation between Ethical and Moral Strength dimension of Leadership Effectiveness and various factors of Job Satisfaction like (Job Concrete factor .071), (Job Abstract factor -.002), (Psycho-Social factor.014),(Economic factor .062), Community/National Growth factor is .026) and with composite score of Job Satisfaction is (.051).The results reveal that there is no significant correlation between ethical and moral strength dimension of Leadership Effectiveness and various factors of Job Satisfaction. No significant correlation was found between Ethical and Moral Strength dimension of Leadership Effectiveness and composite score of Job Satisfaction.

It is clear from table no. 1 that the coefficient of correlation between Adequacy of Communication 


\section{International Journal of Advanced Multidisciplinary Scientific Research (IJAMSR) ISSN:2581-4281}

dimension of Leadership Effectiveness and various factors of Job Satisfaction like (Job Concrete factor .083), (Job Abstract factor -.045), (Psycho-Social factor .059), (Economic factor .013), Community/National Growth factor .069). The results indicate that there is no significant correlation between adequacy of the communication dimension of Leadership Effectiveness and various factors of Job Satisfaction of Secondary School Headmasters. The coefficient of correlation between Adequacy of Communication dimension of Leadership Effectiveness and composite scores of Job Satisfaction is and with a composite score of Job Satisfaction is (.008) which is not significant.

The table no. 1 shows the coefficient of correlation between Operations as a Citizen dimension of Leadership Effectiveness and various factors of Job Satisfaction including composite score. The table shows that coefficient of correlation between Operations as Citizen dimension and various factors of Job Satisfaction like (Job Concrete factor.051), (Job Abstract factor-. 080), (Psycho-Social factor -. 071), (Economic factor -. 070), (Community/National Growth factor is. 130). The results revealed a positive and significant relationship at 0.05 levels between Operations as Citizen dimension of Leadership Effectiveness and National and Community Growth factor of Job Satisfaction and they go together. The Relationship between Operations as a Citizen dimension of Leadership Effectiveness and composite scores of Job Satisfaction (-. 050) which is negative but not significant.

A perusal of table no. 1 further reveals the coefficient of correlation between Composite Score of Leadership Effectiveness and various factors of Job Satisfaction. The results show that the coefficient of correlation between composite score of Leadership Effectiveness \& various factors of Job Satisfaction like (Job Concrete factor -. 019), (Job Abstract factor -. 006), (PsychoSocial factor.029), (Economic factor.056), (Community/National Growth factor. 042) and with a composite score of Job Satisfaction is. 051. The results make it clear that there is no significant correlation between composite score of Leadership Effectiveness and various factors including a composite score of Job Satisfaction.

The above findings are in line with some of the some researchers in the field: Siddique, 2015; Sarwar, et al., 2014; Ali, et al., 2013). Siddique, (2015) revealed that the leadership has a significant relationship with job satisfaction. A significant relationship was found between job satisfaction and transformational leadership style. The results indicated a significant relationship between job satisfaction and transactional leadership style. Sarwar, et al., (2014) found that there are statistically significant relationships between overall transactional leadership and job satisfaction, overall transformational leadership and job satisfaction and laissez-faire leadership and job satisfaction. Ali, et al., (2013) found a positive effect of both transformational and transactional leadership on job satisfaction and organizational commitment, but this effect is more in case of transactional leadership. Importantly, results are challenging the view that both styles of leadership are necessary conditions for leadership.

In light of empirical evidence discussed above, the hypothesis which reads as, "There is a significant relationship between Leadership Effectiveness and Job Satisfaction of Secondary School Headmasters on various (Dimensions \& Composite Score)" is partially accepted. 


\section{Conclusion}

- Positive and significant correlation has been found between interpersonal relations dimension of leadership effectiveness and composite scores of job satisfaction.

- There is a positive and significant relationship between the intellectual operations dimension of leadership effectiveness and job concrete factor of job satisfaction.

- There is a positive and significant relationship between behavioral \& emotional stability dimension of leadership effectiveness and psycho-social factors of job satisfaction.

- There is positively significant relationship between operations as a citizen dimension of leadership effectiveness and community/national growth factor of job satisfaction.

\section{Inferential Suggestions}

- Sensitization programs and workshops should be arranged for Headmasters were in they will be provided inputs on teaching as a profession. So that they will feel the satisfaction of a job.

- Refresher courses should be arranged for Headmasters of the schools so that they will be made skillful to operate as heads of the institutions in their respective schools.

- Orientation courses should be arranged for the head of the institutions. So that they will be oriented about leadership skills. In order to be successful heads of the institutions.

- Job satisfaction is most important to employees, employers and the community at large. The present study provides scope for the enhancement of job satisfaction through structured sensitization; attitude building and skill-based training programs.

- Efforts are needed to improve the infrastructural facilities. An effective job policy, promotional opportunities, service rules, retirement benefits and good working conditions need a careful consideration.

\section{References}

1) Siddique, J. (2015). Job Satisfaction and Leadership Styles: A Study of Malaysian Organizations. Elk

i. Asia Pacific Journal Of
Leadership And Innovation
Management.1(2).

2) Ali, A. Y. S., Sidow, M. A. \& Guleid, H. S. (2013) Leadership Styles and Job Satisfaction: Empirical

i. Evidence from Mogadishu universities, European Journal of Management Sciences and

ii. Economics, 1(1), 1-10.

3) Sarwar, et al., (2014). Impact of Leadership Styles on Job Satisfaction and Organizational

a. Commitment. International Review of Management and Business Research, 4(3).

4) Leithwood, K. (1999). Leadership for school restructuring. Educational Administration Quarterly, 30 (4), 498-518.

5) Taj, H. (2010). Manual for leadership effectiveness scale. Bhargava Bhavan; Agara, national psychological corporation. 
6) Voilet, I., A. (2016). Assessment of the effectiveness of leadership styles \&administrativecompetence of principals in secondary schools in Central Senatorial District of Delta State International journal of Innovative education Research, 4 (3), 1322.

7) Adamu, B. J. \& Ajayi, I. A. (2012). Leadership behavior and communication methods as correlates of administrative effectiveness of heads of academic departments in colleges. Paper presented at $3^{\text {rd }}$ International Conference, Future of Education, Florence, Italy.

8) Ali, et al., (2012). Job satisfaction of head teachers at elementary level, Elixir leadership, management, 49, 10067-10070.

9) Armstrong, M. (2004). Handbook of management and leadership. A guide to managing results. 2nd edition. London \& Philadelphia.

10) Cokluk, O., \& Yllmaz, K. (2010). The relationship between leadership Behaviour and organizational commitment in Turkish primary schools. Bilig, 54 (6), 75-92.

11) Alabi, G., \& Alabi, J. (2014). Understanding the factors that influence leadership effectiveness of deans in Ghana. Council for the development of social science research in Africa, 12(1), 111-132.

12) Blum, M. L., and Naylor, J. C. (1968). Industrial Psychology_It's Theoretical and Social Foundations. New York, Harper and Row.

13) Frank, B. (1986). The deans job satisfaction: Its relationship to organizational structure. Journal of Nursing Education, 25 (2), 59-63.

14) Ghazi, S. R., and Khan, U. A. (2008). Measuring job satisfaction: Influence of gender and school location. The S.U. Jour. of Education, 37, 17-30.

15) Gupta, G. S. (1987). Administrative leadership behaviour as related to the organizational climate of colleges affiliated to Rohilkh and University. Unpublished pH. D Dissertation. Rohilkh University.
16) Harris, J., Martin, B. N., \& Agnew, W. (2004). The characteristics, behavior and training of effective educational/leadership department chairs. Roundtable Presentation at Annual Conference, Kansas City, Missouri.

17) Kauts, A., and Sharma, G. (2017). Leadership effectiveness \& teachers job satisfaction in relation to school effectiveness at secondary stage, MIER Journal of Educational Studies, Trends \& Practices, $7(1), 1-13$.

18) Mocheche, E. K., Bosire, P., \& Raburu, P. (2017). Influence of Gender on Job Satisfaction of Secondary School Teachers in Kenya, International Journal of Advanced and Multidisciplinary Social Science, 3 (2), 40-48.

19) Morrison, R. S., Jones, L., \& Fuller, B. (1997). The relation between leadership style and empowerment on job satisfaction of nurses. Jr. of Nursing Admtr, 27 (5), 27-34. 